\title{
Application of Inquiry Learning Model to Improve Learning Activeness of Class V Natural Resources Conservation Efforts
}

\author{
Siti Yuhanir \\ SDN Negeri Blondo 3 \\ Sabha.amina@gmail.com
}

\section{Article History}

accepted $14 / 11 / 2020$

approved $21 / 11 / 2020$

published 26/11/2020

\begin{abstract}
The purpose of this study was to improve the activeness of students in the subject matter of Natural Resources Conservation Efforts using inquiry learning models. The research conducted was a Classroom Action Research (PTK) in 3 cycles, with each cycle consisting of 1 meeting. The stages of each cycle are planning, implementing, observing, and reflecting. In cycle 1, students who were declared active after observation were $64.58 \%$. In cycle 2, students who were declared active after observation were 88.15 percent. In cycle 3 students who were active after observation were $94.1 \%$. These results indicate that the inquiry learning model can increase the activeness of students, especially the content of science lessons on Natural Resources Conservation Efforts for grade IV SDN Blondo 3.
\end{abstract}

Keywords: activeness, inquiry, natural sciences, natural resources conservation efforts

\section{Abstrak}

Tujuan dari penelitian ini adalah untuk meningkatkan keaktifan peserta didik pada muatan pelajaran IPA materi Upaya Pelestarian Sumber Daya Alam dengan menggunakan model pembelajaran inquiri. Penelitian yang dilakukan adalah Penelitian Tindakan Kelas (PTK) sebanyak 3 siklus, dengan setiap siklusnya terdiri dari 1 kali pertemuan. Tahapan setiap siklusnya adalah perencanaan, pelaksanaan, observasi, dan refleksi. Pada siklus 1 peserta didik yang dinyatakan aktif setelah dilakukan observasi sebanyak $64,58 \%$. Pada siklus 2 peserta didik yang dinyatakan aktif setelah dilakukan observasi sebanyak 88,15 persen. Pada siklul 3 peserta didik yang aktif setelah dilakukan observasi sebanyak $94,1 \%$. Hasil ini menunjukkan bahwa model pembelajaran inquiri dapat meningkatkan keaktifan peserta didik khususnya muatan pelajaran IPA materi Upaya Pelestarian Sumber Daya Alam kelas IV SDN Blondo 3.

Kata kunci: keaktifan, inquiri, ipa, upaya pelestarian sumber daya alam

Social, Humanities, and Education Studies (SHEs): Conference Series https://jurnal.uns.ac.id/shes

p-ISSN 2620-9284

e-ISSN 2620-9292 


\section{PENDAHULUAN}

Pendidikan merupakan usaha agar manusia dapat mengembangkan potensi dirinya melalui proses pembelajaran atau dengan cara lain yang dikenal dan diakui oleh masyarakat. "Sistem pendidikan harus mampu menjamin pemerataan kesempatan pendidikan, peningkatan mutu serta relevansi dan efisiensi manajemen pendidikan untuk menghadapai tantangan sesuai dengan tuntutan perubahan lokal, nasional, dan global sehingga perlu dilakukan pembaharuan pendidikan terencana, terarah, dan berkesinambungan" (UU No. 20 Tahun 2003 tentang Sistem Pendidikan Nasional).

UU No 20 Tahun 2003 pasal 17 menjelaskan bahwa "Pendidikan dasar merupakan jenjang pendidikan yang melandasi jenjang pendidikan menengah". Dengan demikian Sekolah Dasar (SD) merupakan salah satu lembaga pendidikan formal yang menyiapkan peserta didik masuk ke jenjang pendidikan menengah yang memberi bekal pengetahuan dan keterampilan dasar yang bermanfaat bagi peserta didik sesuai dengan tingkat perkembangannya.

Berdasarkan hal tersebut, pendidik sebagiknya mengedepankan visi belajar abad ke - 21 seperti yang dikemukakan oleh Delors (Unesco, 1996), seorang pendidik harus mampu menciptakan teori belajar sepanjang hayat (life long learning), dan bagaimana belajar (learning how to learn). Teori ini bertumpu pada empat pilar pendidikan yaitu learning to know (belajar mengetahui), learning to do ( belajar berbuat), learning to be ( belajar menjadi dirinya), dan learning to live together (belajar hidup bersama) (Ingridwati Kurnia, dkk, 2008: 1-3). Dengan demikian seorang guru harus mampu menciptakan suasana pembelajaran dengan baik. Proses pemilihan pendekatan, metode, strategi, dan teknik dilakukan dengan mempertimbangkan situasi, kondisi, kebutuhan dan karakteristik peserta didik yang dihadapi dalam rangka tujuan pembelajaran.

Melihat hasil observasi, proses pembelajaran yang demikian belum dilaksanakan sepenuhnya di SD Negeri Blondo 3. Proses pembelajaran masih didominasi oleh guru. Guru menjelaskan materi tanpa memberikan contoh secara konkret. Selain itu kurangnya media belajar berupa alat peraga dalam proses pemberian materi. Guru belum kreatif membuat alat peraga sederhana yang menunjang proses pembelajaran. Alat peraga yang tersedia tidak dipergunakan.

Hal demikian menyebabkan keaktifan peserta didik rendah, tidak ada interaksi dan komunikasi yang baik pada proses pembelajaran. Peserta didik cenderung pasif. Apabila guru menyampaikan pertanyaan, hanya beberapa peserta didik yang berani untuk menjawabnya.

Berdasarkan uraian di atas, perlu adanya penerapan sebuah model pembelajaran yang inovatif, menarik, membuat keaktifan belajar peserta didik meningkat. Salah satunya adalah dengan menerapkan model pembelajaran inkuiri. Model pembelajaran ini menekankan kepada aktivitas peserta didik secara maksimal dalam proses mencari dan menemukan sendiri jawaban dari suatu masalah. Artinya model pembelajaran ini menempatkan peserta didik sebagai subjek belajar. Dalam proses pembelajaran, peserta didik tidak hanya berperan sebagi penerima pelajaran melalui penjelasan guru secara verbal, tetapi mereka berperan untuk menemukan sendiri inti dari materi pelajaran itu sendiri. Guru hanya sebagai fasilitator dan motivator belajar peserta didik.

Berdasarkan latar belakang masalah yang dikemukakan di atas, maka rumusan masalah penelitian ini adalah bagaimanakah peningkatan keaktifan belajar melalui model pembelajaran inkuiri pada peserta didik kelas IV SDN Blondo 3. Dan apakah penerapan model pembelajaran inkuiri dapat meningkatkan keaktifan belajar peserta didik kelas IV SDN Blondo 3. 
Tujuan dari penelitian ini adalah meningkatkan keaktifan belajar materi " Upaya Pelestarian SDA" pada peserta didik kelas IV SD Negeri Blondo 3 melalui penerapan model pembelajaran inkuiri.

\section{METODE}

Penelitian ini adalah penelitian tindakan kelas (PTK). PTK yaitu penelitian tindakan (action research) yang dilakukan dengan tujuan memperbaiki mutu praktik pembelajaran di kelas (Arikunto, 2014:2). Kemmis \& Mc. Tagart (Arikunto, 2014:16) menyatakan bahwa terdapat 4 langkah utama dalam pelaksanaan PTK yaitu: 1) perencanaan (plan); 2) tindakan (act); 3) pengamatan (observe); 4) refleksi (reflect)

Tahap perencanaan merupakan kegiatan merencanakan tindakan yang akan dilakukan untuk setiap siklus sebelum melaksanakan tindakan di kelas. Tahap kedua adalah tindakan yang dilakukan peneliti sesuai yang sudah direncanakan pada tahap perencanaan sebagai upaya perbaikan yang diinginkan. Tahap pengamatan sebagai kegiatan mengamati proses pembelajaran untuk mengetahui hasil dari tindakan yang telah dilakukan selama pembelajaran.Tahap refleksi bertujuan untuk merenungkan kembali tindakan yang telah dilakukan pada proses pembelajaran secara menyeluruh berdasarkan data yang terkumpul. Penelitian ini dilaksanakan pada peserta didik kelas IV SDN Blondo 3 Tahun Pelajaran 2020/ 2021 semester 1 selama tiga siklus secara daring menggunakan aplikasi zoom dengan satu kali pertemuan setiap siklusnya. Siklus 1 dilaksanakan pada tanggal 2 November 2020. Siklus 2 dilaksanakan pada tanggal 7 November 2020. Siklus 3 dilaksanakan pada tanggal 20 November 2020. Teknik pengumpulan data yang digunakan dalam penelitian ini adalah wawancara, observasi, dan dokumentasi. Untuk penelitian keaktifan dilakukan pengambilan data menggunakan lembar observasi.

\section{HASIL DAN PEMBAHASAN}

Pengamatan awal (pra siklus) proses pembelajaran tentang Upaya Pelestarian Sumber Daya Alam di kelas IV dilaksanakan pada minggu ke 3 bulan Oktober. Peneliti bertindak sebagai observer dan guru kelas IV (Bapak Syaiful Jihad, S.Pd.) bertindak sebagai guru/ pengajar. Peneliti mengamati Rencana Pelaksanaan Pembelajaran (RPP) yang digunakan guru dan proses pembelajaran tentang Sumber Daya Alam yang sedang berlangsung. Berdasarkan observasi awal penilaian proses siswa oleh peneliti terkait sikap siswa yaitu: keaktifan dan perhatian siswa di dalam proses pembelajaran diperoleh data penilaian proses prasiklus siswa. Hasil keaktifan belajar yang dilakukan pada pengamatan proses pembelajaran pra siklus memperoleh ratarata $51,82 \%$ pada kriteria "Kurang". Observasi dilakukan pada proses pembelajaran, yang terdiri dari 8 indikator keaktifan belajar. Berikut rata- rata prosentase hasil rekapitulasi untuk masing-masing indikaktor keaktifan belajar pada siswa kelas IV SDN Blondo 3.

Tabel 1. Rata-rata Persentase Observasi Keaktifan Peserta Didik Pra Siklus

\begin{tabular}{llll}
\hline No & \multicolumn{1}{c}{ Indikator Keaktifan } & Prosentase & Kriteria \\
& & & \\
\hline 1 & $\begin{array}{l}\text { Keinginan menemukan informasi } \\
\text { sendiri pengetahuan dan }\end{array}$ & & Kurang \\
& pengenalan dalam pembelajaran. & & \\
2 & Mampu melaksanakan Observasi & $48,96 \%$ & Kurang \\
3 & Keberanian bertanya tentang hal- & $54,17 \%$ & Kurang \\
\hline
\end{tabular}




\begin{tabular}{llrl}
\hline 4 & \multicolumn{2}{l}{$\begin{array}{l}\text { hal yang belum dipahami. } \\
\text { Keberanian } \\
\text { pendapat } \\
5\end{array}$} & $\begin{array}{l}\text { Menyampaikan } \\
\text { pembelajaran }\end{array}$ \\
6 & $\begin{array}{l}\text { Peserta didik antusias mengikuti } \\
\text { pembelajaran }\end{array}$ & $51,04 \%$ & Kurang \\
7 & $\begin{array}{l}\text { Peserta didik membaca secara } \\
\text { teliti dan seksama teks bacaan. }\end{array}$ & $53,13 \%$ & Kurang \\
8 & $\begin{array}{l}\text { Peserta didik mengerjakan } \\
\text { evaluasi pada googleform }\end{array}$ & $52,08 \%$ & Kurang \\
Rata- rata & $51,82 \%$ & Kurang \\
\hline
\end{tabular}

Berdasarkan tabel di atas, Hasil keaktifan belajar yang dilakukan pada pengamatan proses pembelajaran pra siklus memperoleh rata-rata $51,82 \%$ dengan kriteria "Kurang" Setelah mengetahui data tersebut, peneliti menindaklanjuti dengan perubahan pembelajaran yang diterapkan antara pra siklus dan siklus I. Jika pada pra siklus interaksi pembelajaran masih menggunakan wa dan sumber hanya buku materi dalam pembelajaran, maka pada siklus I pembelajaran menggunakan zoom dan menampilkan video dalam pembelajaran.

Pada siklus 1 pembelajaran dilaksanakan selama satu kali pertemuan. Siklus 1 dilaksanakan dalam satu hari pembelajaran yaitu hari Senin, 02 November 2020 di ruang kelas IV SDN Blondo 3. Pada tahap ini, guru melaksanakan pembelajaran melalui zoom dan membahas tentang Upaya pelestarian Sumber Daya Alam. Pembelajaran menggunakan model inkuiri dilaksanakan dengan 6 langkah yaitu orientasi, merumuskan masalah, mengajukan hipotesis, mengumpulkan data, menguji hipotesis, merumuskan kesimpulan. Berikut ini adalah hasil observasi Keaktifan Belajar peserta didik Siklus 1

Tabel 2. Rata-rata Persentasi Observasi Keaktifan Peserta Didik Siklus I

\begin{tabular}{|c|c|c|c|}
\hline No & Indikator Keaktifan & Prosentase & Kriteria \\
\hline 1 & $\begin{array}{l}\text { Keinginan menemukan informasi } \\
\text { sendiri pengetahuan dan } \\
\text { pengenalan dalam pembelajaran. }\end{array}$ & $64,58 \%$ & Cukup \\
\hline 2 & Mampu melaksanakan Observasi & $67,71 \%$ & Tinggi \\
\hline 3 & $\begin{array}{l}\text { Keberanian bertanya tentang hal- } \\
\text { hal yang belum dipahami. }\end{array}$ & $69,79 \%$ & Tinggi \\
\hline 4 & $\begin{array}{l}\text { Keberanian mengajukan } \\
\text { pendapat }\end{array}$ & $64,58 \%$ & Cukup \\
\hline 5 & $\begin{array}{l}\text { Menyampaikan } \\
\text { pembelajaran }\end{array}$ & $72,92 \%$ & Tinggi \\
\hline 6 & $\begin{array}{l}\text { Peserta didik antusias mengikuti } \\
\text { pembelajaran }\end{array}$ & $78,13 \%$ & Tinggi \\
\hline 7 & $\begin{array}{l}\text { Peserta didik membaca secara } \\
\text { teliti dan seksama teks bacaan. }\end{array}$ & $63,54 \%$ & Cukup \\
\hline 8 & $\begin{array}{l}\text { Peserta didik mengerjakan } \\
\text { evaluasi pada googleform }\end{array}$ & $72,92 \%$ & Cukup \\
\hline \multicolumn{2}{|c|}{ Rata- rata } & $69,01 \%$ & Tinggi \\
\hline
\end{tabular}


Berdasarkan tabel di atas maka terjadi peningkatan antara pra siklus dan siklus 1 . Hasil keaktifan belajar yang dilakukan pada proses pembelajaran siklus I memperoleh rata-rata 69,01 \% pada kriteria "Tinggi". Peserta didik mengalami peningkatan keaktifan belajar. Pada pra siklus persentase rata- rata keaktifan peserta didik hanya $51,82 \%$. Tetapi pada siklus 1 rata- rata persentase keaktifan peserta didik meningkat menjadi $69,01 \%$. Berdasarkan refleksi pada siklus 1 maka diputuskan untuk melanjutkan ke siklus 2 dikarenakan belum mencapai ketuntasan klasikal yang diharapkan. Siklus 2 masih membahas di KD yang sama yaitu Upaya Pelestarian Sumber Daya Alam. Pembelajaran dengan model inkuiri dilaksanakan dengan 6 langkah model inkuiri sama seperti siklus 1 . Berikut adalah rata- rata persentase keaktifan peserta didik pada siklus II yang bisa dilihat pada tabel berikut.

Tabel 3. Rata-rata Persentase Keaktifan Peserta Didik Siklus II

\begin{tabular}{|c|c|c|c|}
\hline No & Indikator Keaktifan & Prosentase & Kriteria \\
\hline 1 & $\begin{array}{l}\text { Keinginan menemukan informasi } \\
\text { sendiri pengetahuan dan } \\
\text { pengenalan dalam pembelajaran. }\end{array}$ & $84,38 \%$ & $\begin{array}{l}\text { Sangat } \\
\text { tinggi }\end{array}$ \\
\hline 2 & Mampu melaksanakan Observasi & $88,54 \%$ & $\begin{array}{l}\text { Sangat } \\
\text { tinggi }\end{array}$ \\
\hline 3 & $\begin{array}{l}\text { Keberanian bertanya tentang hal- } \\
\text { hal yang belum dipahami. }\end{array}$ & $89,58 \%$ & $\begin{array}{l}\text { Sangat } \\
\text { tinggi }\end{array}$ \\
\hline 4 & $\begin{array}{l}\text { Keberanian mengajukan } \\
\text { pendapat }\end{array}$ & $90,63 \%$ & $\begin{array}{l}\text { Sangat } \\
\text { tinggi }\end{array}$ \\
\hline 5 & $\begin{array}{l}\text { Menyampaikan } \\
\text { pembelajaran }\end{array}$ & $83,33 \%$ & $\begin{array}{l}\text { Sangat } \\
\text { tinggi }\end{array}$ \\
\hline 6 & $\begin{array}{l}\text { Peserta didik antusias mengikuti } \\
\text { pembelajaran }\end{array}$ & $91,67 \%$ & $\begin{array}{l}\text { Sangat } \\
\text { tinggi }\end{array}$ \\
\hline 7 & $\begin{array}{l}\text { Peserta didik membaca secara } \\
\text { teliti dan seksama teks bacaan. }\end{array}$ & $86,46 \%$ & $\begin{array}{l}\text { Sangat } \\
\text { tinggi }\end{array}$ \\
\hline \multirow[t]{2}{*}{8} & $\begin{array}{l}\text { Peserta didik mengerjakan } \\
\text { evaluasi pada googleform }\end{array}$ & $90,63 \%$ & $\begin{array}{l}\text { Sangat } \\
\text { tinggi }\end{array}$ \\
\hline & Rata- rata & $88,15 \%$ & $\begin{array}{l}\text { Sangat } \\
\text { tinggi }\end{array}$ \\
\hline
\end{tabular}

Berdasarkan tabel di atas maka terjadi peningkatan keaktifan peserta didik pada siklus I dan siklus II. Hasil keaktifan belajar yang dilakukan pada proses pembelajaran siklus II memperoleh rata-rata $88,15 \%$ pada kriteria "Sangat tinggi". Sedangkan hasil keaktifan belajar peserta didik di siklus I hanya 69,01\%. Observasi dilakukan pada proses pembelajaran, yang terdiri dari 8 indikator keaktifan belajar.

Setelah melakukan refleksi pada siklus II, maka diputuskan untuk melanjutkan pada siklus III. Hal ini dilakukan agar mengetahui sejauh mana penerapan pembelajaran inkuiri ini tidak hanya meningkatkan tetapi juga mempertahankan keaktifan peserta didik. Pada siklus III, materi yang diajarkan masih di KD yang sama. Peserta didik berdiskusi untuk memprediksi kondisi hutan di Kalimantan tahun 2030. Hasil pengamatan keaktifan peserta didik dapat dilihat pada tabel berikut. 
SHEs: Conference Series 3 (3) (2020) 925-931

Tabel 3. Rata-rata Persentase Keaktifan Peserta Didik Siklus III

\begin{tabular}{|c|c|c|c|}
\hline No & Indikator Keaktifan & Prosentase & Kriteria \\
\hline 1 & $\begin{array}{l}\text { Keinginan menemukan informasi } \\
\text { sendiri pengetahuan dan } \\
\text { pengenalan dalam pembelajaran. }\end{array}$ & $89,58 \%$ & $\begin{array}{l}\text { Sangat } \\
\text { tinggi }\end{array}$ \\
\hline 2 & Mampu melaksanakan Observasi & $91,67 \%$ & $\begin{array}{l}\text { Sangat } \\
\text { tinggi }\end{array}$ \\
\hline 3 & $\begin{array}{l}\text { Keberanian bertanya tentang hal- } \\
\text { hal yang belum dipahami. }\end{array}$ & $90,63 \%$ & $\begin{array}{l}\text { Sangat } \\
\text { tinggi }\end{array}$ \\
\hline 4 & $\begin{array}{l}\text { Keberanian mengajukan } \\
\text { pendapat }\end{array}$ & $91,67 \%$ & $\begin{array}{l}\text { Sangat } \\
\text { tinggi }\end{array}$ \\
\hline 5 & $\begin{array}{l}\text { Menyampaikan hasil } \\
\text { pembelajaran }\end{array}$ & $87,50 \%$ & $\begin{array}{l}\text { Sangat } \\
\text { tinggi }\end{array}$ \\
\hline 6 & $\begin{array}{l}\text { Peserta didik antusias mengikuti } \\
\text { pembelajaran }\end{array}$ & $94,79 \%$ & $\begin{array}{l}\text { Sangat } \\
\text { tinggi }\end{array}$ \\
\hline 7 & $\begin{array}{l}\text { Peserta didik membaca secara } \\
\text { teliti dan seksama teks bacaan. }\end{array}$ & $90,63 \%$ & $\begin{array}{l}\text { Sangat } \\
\text { tinggi }\end{array}$ \\
\hline \multirow[t]{2}{*}{8} & $\begin{array}{l}\text { Peserta didik mengerjakan } \\
\text { evaluasi pada googleform }\end{array}$ & $100 \%$ & $\begin{array}{l}\text { Sangat } \\
\text { tinggi }\end{array}$ \\
\hline & Rata- rata & $94,1 \%$ & $\begin{array}{l}\text { Sangat } \\
\text { tinggi }\end{array}$ \\
\hline
\end{tabular}

Berdasarkan tabel di atas maka terjadi peningkatan keaktifan peserta didik pada siklus III. Hasil keaktifan belajar yang dilakukan pada proses pembelajaran siklus III memperoleh rata-rata $94,1 \%$ pada kriteria "Sangat tinggi".

Dari tiga siklus yang sudah dilaksankan selama 3 kali pertemuan dapat dipastikan bahwa model pembelajaran inkuiri dapat meningkatkan keaktifan belajar peserta didik pada muatan pelajaran IPA materi Upaya Pelestarian Sumber Daya Alam kelas IV SDN Blondo 3. Hal ini sesuai teori yang di ungkap AL Tabany. Al Tabany (2014: 78) menyebutkan bahwa inkuiri yang dalam bahasa Inggris inquiry, berarti pertanyaan, atau pemeriksaanm penyelidikan. Inkuiri sebagai suatu proses umum yang dilakukan manusia untuk mencari dan memahami informasi. Gulo (2002) dalam Trianto (2011: 166), menyatakan strategi inkuiri berarti suatu rangkaian kegiatan belajar yang melibatkan secara maksimal seluruh kemampuan peserta didik untuk mencari dan menyelidiki secara sistematis, kritis, logis, analitis, sehingga mereka dapat merumuskan sendiri penemuannya dengan penuh percaya diri. Pengajaran berdasarkan inkuiri adalah suatu strategi yang berpusat pada peserta didik di mana kelompok-kelompok peserta didik dihadapkan pada suatu persoalan atau mencari jawaban terhadap pertanyaan-pertanyaan di dalam suatu prosedur san struktur kelompok yang digariskan secara jelas (Hamalik, 1991).

Dalam model pembelajaran ini, peserta didik didorong untuk aktif dalam pembelajaran seperti aktif menemukan sendiri jawaban dari suatu masalah yang dipertanyakan dari berbagai sumber. Menurut Gulo seperti yang dikutip oleh Al Tabany (2014: 83), menyatakan bahwa inkuiri tidak hanya mengembangkan kemampuan intelektual tetapi seluruh potensi yang ada, termasuk pengembangan emosional.

\section{SIMPULAN}

Penerapan model pembelajaran Inkuiri dapat meningkatkan keaktifan belajar peserta didik pada muatan pelajaran IPA materi Upaya Pelestarian Sumber Daya Alam 
pada siswa kelas IV SD Negeri Blondo 3 tahun pelajaran 2020/ 2021 dengan langkahlangkah sebagai berikut: orientasi, rumusan masalah, hipotesis, mengumpulkan data, menguji hipotesis, dan merumuskan kesimpulan. Hal ini juga bisa dilihat dari peningkatan persentase rata- rata skor observasi keaktifan dari kondisi pra siklus $51,82 \%$ (kurang) setelah dilakukan tindakan pada siklus I meningkat menjadi $69,01 \%$ (tinggi), pada siklus II 88,15\% (sangat tinggi) dan pada siklus III menjadi $94,1 \%$ (sangat tinggi).

\section{DAFTAR PUSTAKA}

Al-Tabany, Trianto Ibnu Badar. (2014). Mendesain Model Pembelajaran Inovatif, Progresif, dan Kontekstual. Jakarta: Prenadamedia Group.

Depdiknas .(2003). Undang-undang RI No.20 tahun 2003.tentang sistem pendidikan nasional.

Dimyati Mudjiono. (2002). Belajar dan Pembelajaran. Jakarta: Rineka Cipta

Hamalik, Oemar.1991. Pendidikan Guru Konsep dan Strategi, Mandar Maju. Bandung.Depdikbud

Inggritwati Kurnia, dkk. (2008). Perkembangan Belajar Peserta Didik. Jakarta:

Direktorat Jendral Pendidikan Tinggi Departemen pendidikan Nasional.

Masidjo, Ign. (1995). Penilaian Pencapaian Hasil Belajar Peserta didik di Sekolah. Yogyakarta: Kanisius.

Moh. Dimyati dan Moedjiono. 1991/1992. Strategi Belajar Mengajar. Depdikbud Diektorat Jendral Pendidikan Tinggi Proyek Pembinaan Tenaga Kependidikan.

Niyarti Dyas Pratiwi. 2013. Upaya Meningkatkan Keaktifan Belajar IPA Dengan Pendekatan Inkuiri Bagi Peserta didik Kelas IV SD Negeri Karanganyar Ngemplak Sleman. Yogyakarta: UNY

Sugiyono. 2010. Merode Penelitian Kuantitatif, Kualitatif, dan R\&D. Bandung: Alfabeta

Suharsimi Arikunto. 2010. Prosedur Penelitian: Suatu Pendekatan Praktik. Jakarta: Rineka Cipta 2014. Penelitian Tindakan Kelas. Jakarta: Bumi Aksara

Wina Sanjaya. 2006. Strategi Pembelajaran Berorientasi Standar Proses Pendidikan. Jakarta: Prenada Media. 